\title{
A REGULATORY SMALL LOAN LAW SOLVES LOAN SHARK PROBLEM
}

\author{
J. A. A. BURNQUIST*
}

The Minnesota Small Loan Act, ${ }^{1}$ based substantially on the Sixth Draft of the Uniform Small Loan Law, was passed early in the r939 legislative session and was signed by Governor Harold E. Stassen on February 15, I939. The effective date of the Act, June I, 1939, marked the end of the "loan shark" era and the beginning of regulated, licensed lending of small sums in Minnesota.

A history of events leading to eventual passage of the Minnesota Small Loan Act probably is characteristic of experiences in other states in most respects. However, a review of the usurious loan problem that existed and how it was corrected in Minnesota may not be clearly understood without a brief review of the economic structure and population distribution of the state.

Minnesota is essentially an agricultural and mining state, although in recent years, it has gradually changed its economic pattern to achieve a desirable balance between manufacturing, agriculture, trade, and service. Minnesota's population in $195^{\circ}$ was $2,982,483,{ }^{2}$ with about one-third of the total centered in the large metropolitan area of Minneapolis ( $195^{\circ}$ population, 521,718) and St. Paul (1950 population, 311,349). Population centers in Minnesota drop sharply to Duluth, at the head of the Great Lakes, handling the bulk of iron ore shipments from northern Minnesota mines, with a population of 104,5II, and Rochester, St. Cloud, Winona, and Austin, located in agricultural areas, with populations in the 20,000 to 30,000 class. There are only eleven other cities in Minnesota, outside the metropolitan area of Minneapolis-St. Paul, with populations in the 10,000 to 20,000 class.

In size Minnesota is eleventh in the union with an area of $84,286.53$ square miles. It ranks as the fifth leading state in total agricultural production. It poured more than $143,788,000$ tons of iron ore into the nation's blast furnaces during $195 \mathrm{I}$ and 1952 ( 65 per cent of the country's total for that period), and does an estimated $\$ 200,000,000$ in tourist business annually. Yet, due to the extreme concentration of population in the Minneapolis-St. Paul area, and to a lesser degree in Duluth, practically all of the activities of illegal lenders prior to passage of the small loan law, and the greater share of consumer lending service of licensed lenders since 1939 have been concentrated in these focal points. Therefore, a review of the

- B.A. I902, Carleton College; M.A. 1904, Columbia University; LL.B. 1905, University of Minnesota; LL.D. I920, Carleton College; Phi Beta Kappa, Order of the Coif. Member, Minnesota House of Representatives Ig0g and I9II sessions; Lieutenant Governor, I912 and I914; Governor of Minnesota, Igr5 to 1921. Attorney General, State of Minnesota, 1938 to date. President, National Association of Attorneys General, 1949.

${ }^{x}$ Minn. Stat. AnN. c. 56; Laws of Minn. I939, c. 12.

2 Population Figures, etc., from Legislative Manual, Minnesota, 1953. 
usurious loan situation in Minnesota previous to passage of the Small Loan Act and the activity towards final enactment will necessarily relate to conditions in the large, industrial area of Minneapolis-St. Paul. The problem, though primarily local in nature, was to be resolved only by passage of a general law.

\section{Recognimion of Usurious Loan Situation and Early Efforts to Pass Small Loan Legislation}

For the purposes of this paper, action taken by the legislature in 1923 will be considered as the first serious effort to correct the evils of high rate lending of small sums in Minnesota by effective legislation. During the 1923 session, sixteen years prior to eventual passage of a small loan law, the House passed a bill modeled after the then current draft of the Uniform Small Loan Law. However, a companion measure met defeat in the Senate.

The inadequacy of legislation in Minnesota governing loans to consumers in I923 is apparent upon review of the laws on interest existing at that time. The general maximum contract rate of interest was reduced from to per cent per annum to 8 per cent per annum by amendments passed in $1923 .^{3}$ The penalty for contracting for or taking a larger interest return is forfeiture of both the principal and the interest. In such cases an appropriate civil suit may be brought by the borrower to cancel the entire obligation. The only exception to this maximum interest rate in rg23 was the statute relating to so-called "salary loans" and "chattel mortgage loans." Under this exception, loans up to $\$ 200$ in amount could be made by licensed corporations at a maximum of I per cent per month, or 12 per cent per annum, with the addition of certain fixed charges restricted to loans secured by chattel mortgages, and varying with the amount of the loan. An act relating to the formation, of credit unions authorized to loan to members at I per cent per month was passed in r925. A Morris Plan bank was established in Minneapolis in 1917 and one or two other industrial lenders operating on the "Morris Plan" at that time did not have exact legal status until the enactment in 1933 of the law relating to Industrial Loan and Thrift Companies. ${ }^{6}$ Only a few semi-philanthropic lenders were licensed under the I-per-cent-per-month-\$200-maximum-salary-and-chattel-mortgage loan provision and practically all small loans to wage earners in Minnesota were made by unlicensed lenders.

Again, in 1927 , a bill based substantially on the Uniform Small Loan Law draft was introduced in both the House and Senate. The House bill first was defeated after hearings by the Welfare Committee, but on reconsideration it was recommended to pass by that committee. The companion measure was defeated in the Senate. However, the gravity of the situation and widespread interest prompted the

${ }^{3}$ Misis. Stat. ANs. c. 334; Min.s. Stat. Anv. $\$ 334.01$, amended by Laws of Minn. 1927, c. 70 .

- Salary loans and chattel mortgage loans were regulated by Laws 1913, c. $439, \$ \$ 1$ and 2 , as amended by Laws 1915, c. 117, \$1. Those sections were repealed by a provision of the Minnesota Small Loan Act, Laws 1939, c. 12.

Minn. Stat. Anv. c. 52: Laws of Minn. 1925, c. 206.

${ }^{6}$ Minin. Stat. Aviv. c. 53; Laws of Minn. 1933, c. 246. 
appointment of an interim committee in the House to make a study of small loan legislation. This committee made a thorough investigation of conditions in Minnesota and interviewed public officials and welfare leaders in Illinois, Indiana, Pennsylvania, New Jersey, New York, Connecticut, and Massachusetts to determine the effectiveness of small loan legislation in those states. The report of the Interim Committee to the r929 Legislature ${ }^{7}$ contained details as to the method of investigation, its findings, and recommendations for legislation. Although the 1929 Legislature failed to pass small loan legislation as recommended, the findings of the Interim Committee did acknowledge the evils of loan shark activities and the merits of sound small loan legislation which were recognized later in Minnesota by passage of the Small Loan Law in 1939. A summary of the most significant findings follows:

That the general usury laws of this state and of other states are such as to render it impossible for the average borrower to obtain money at a rate of interest within the limit fixed by law.

That the necessitous borrower, unable to borrow at banks or elsewhere at legal rates, will and does borrow from other sources at higher rates.

That to meet the needs of this large class of borrowers who cannot obtain money at legal rates of interest the loan shark has appeared, supplying the need, but at unreasonable and extortionate rates of interest.

That in the large industrial centers of Minnesota, as in similar centers of population in other states where effective legislation has not been enacted, loan sharks do a thriving business based upon rates of interest which range from 120 to 400 per cent per annum and higher.

That the loan shark by threats and intimidation preys upon the weakness and ignorance of the borrower with whom he deals.

That laws such as the general usury law of this State are ineffective in curbing the loan shark evil, because they are arbitrary and unsound in principle in that they do not make proper allowance for the various types of loans, the difference in credit and security possessed by borrowers and the elements of expense involved in the making of loans.

That to legalize the lending of small sums of money at prescribed rates in excess of the general maximum interest rate, fair both to lender and borrower, with provision for State licensing, inspection and supervision of the lender, offers the only practical method of exterminating the loan shark.

That the legalization of a rate of $3 \frac{1}{2} \%$ per month on loans of $\$ 300$ or less does not interfere with or jeopardize the borrower who now is capable of obtaining a loan at a bank or elsewhere at banking rates of interest.

That legislation of the character embodied in the uniform law has received the approval and endorsement everywhere of organizations and individuals who have given the matter consideration.

As shown in the summary above, the problem and its solution were well laid out ten years prior to action taken. The findings were general in nature, but

\footnotetext{
${ }^{7}$ Mabeth H. Paige, Chairman, R. J. Quinlivan, Guy C. Dilley, and J. R. Schweitzer, Report of the INterim Committee of the House of Representatives, State of Minnesota, on Small Loan LEGTSLATION (1929).
} 
specific cases, exposed in formal investigations subsequently made, proved their soundness and correctness.

Following the defeat of the small loan bill in 1929, sporadic bills to control small loans with varying degrees of support and effectiveness were introduced and lost in the legislative sessions through 1935 .

\section{Intensified Txposure of Usurious Lending Activity Culminating in Enactment of Smali Loan Law in I939}

By the 1937 session, the voice of public opinion was intense and determined against the activities of the loan sharks in Minnesota, particularly in the large metropolitan areas of Minneapolis and St. Paul. The Better Business Bureau of Minneapolis, the Minneapolis Legal Aid Society, Family Service of St. Paul, other public welfare agencies of both cities, as well as many other community organizations and leaders took an active interest in, and sought a solution to the cases of hardship and distress of harassed borrowers caused by the flagrant flaunting of the usury law by a multitude of "high rate" lenders. A national magazine, "Today," in the December 16, 1936 issue, carried an article by Marc A. Rose entitled, "Sharks in Minnesota." Just prior to the opening of the 1937 legislative session, highlights of the article were printed in many of the leading newspapers in the state. The following quotes from the article summarize the situation and the general plan of the drive to correct it:

Loan sharks are tearing a $\$ 5,000,000$ chunk out of the annual income of the people of Minnesota and carrying most of it off to other states. The bulk of the money is taken from the wage and salary earners of the Twin Cities . . . More than roo loan offices, good and bad, do business in Minneapolis and St. Paul. Many advertise extensively ... The Twin Cities are determined to do something about it when the Minnesota Legislature meets in January. Social agencies, bankers, newspapers and other leaders of the community have tried before to wipe out the great bootleg loan business but they have failed ... Loan shark lobby has succeeded again and again to defeat the bill to regulate small loans. It was fairly easy to do ... Smearing of motives was effective but the real difficulty has always been that Minnesota is predominantly a rural state despite her great cities ... The lawmaker from the farming district simply could not see where the problem touched him, could hardly be made to see that it was important to anyone save an "improvident" and "no-account" fringe of city workmen. That is a wholly mistaken conception for more than half the borrowers who get into the toils of loan sharks are skilled workmen and white collar people ... In the Twin Cities, 50,000 are continuously in debt, paying $\$ 5,000,000$ a year interest on $\$ 2,000,000$ in outstanding loans. One of the largest offices is estimated at $\$ 50,000$ outstanding; the average office handles $\$ 20,000$ capital ... The money lender is not a useless parasite, he is most essential to societyvery fact he can collect $240 \%$ shows how desperately he is needed. Nobody submits to such a gouge if he can borrow money cheaply.

Although the campaign to pass small loan legislation was intensified in 1937, the bill was again defeated in the House.

Following the 1937 session, a direct effort was instituted by social agencies sup-

'Today, Dec. 19, 1936, p. 18. 
porting passage of effective small loan legislation to secure specific information and statistics to show the magnitude of the problem as it actually existed in the Minneapolis area. Prior to 1937 there were comparatively few statistics available on the operations of usurious lenders within the State. An investigation conducted by the Minneapolis Legal Aid Society in 1937 and the data obtained by the Better Business Bureau of Minneapolis in preparing a special report on high rate loan companies provided the insight on the problem needed to rally public opinion in favor of small loan legislation. A study of typical cases of Minneapolis wage earners in Bankruptcy Court and their involvement with high rate lenders also contributed to the mass of evidence showing the need for control of lending small sums. The Hennepin County Bar Association had a committee actively studying and resolving cases of distress caused or aggravated by high rate lending tactics. A Citizens Committee composed of scores of leading citizens in Minneapolis also became active in the drive. In the fall of 1938 , a series of actions were commenced by the state on relation of the county attorney of Hennepin County to enjoin several loan firms from conducting a small loan business in the city of Minneapolis in which usury was invariably exacted. These cases also served as a rallying point for supporters of control by legislation.

The results of the study made by the Legal Aid Society of Minneapolis, beginning in $19377^{\circ}$ disclosed that:

over a period of one year, a total of 307 loans made by 208 borrowers were carefully studied. It was found that there were in operation in Minneapolis alone, at least sixty different loan companies which could be established definitely and conclusively as companies which were engaged in the business of lending money at rates far in excess of all known legal maximums. The disparity in numbers alone between the legitimate lenders and these usurious lenders is significant. The average interest rate on these loans was found to be approximately 224 per cent per annum, with rates in single instances running in excess of 1,000 per cent. The average monthly income of borrowers from these companies was approximately $\$ 90$ to $\$ 100$. By far the greater proportion of borrowers were married persons with an average of two or three dependents, exclusive of husband or wife. Two hundred and seventeen of these loans were for periods of six months or less. The longest loan period recorded in the investigation was forty months, and the shortest-term loan, one of $\$ 5$ to be repaid in one week with $\$ 1$ interest. Of the amounts borrowed, 257 were loans of $\$ 50$ or less, 58 being loans of $\$ 5^{\circ}$ each, and coincidentally, $5^{8}$ being loans of $\$ 25$. Only $2 \mathrm{r}$ loans were in excess of $\$$ roo.

The investigation of high rate loan companies in Minneapolis conducted by the Better Business Bureau covered a twelve month period from July I, I938. While it was not completed until after passage of the Small Loan Law, preliminary findings and many individual cases of distress caused by high rate lending activities were publicly exposed and effectively presented to the legislative committees in support of sound small loan legislation. As to the scope of the investigation by the Better Business Bureau: $:^{10}$

\footnotetext{
- Bachelder, The Small Loan Business Unregulated, 25 AnNars 35, 36-37 (Sept. 1939).

${ }^{10}$ Speciar Report on Investigation of High Rite Loan Companies in Minneapolis, July I, 1938
} 
During the twelve months period from July $\mathrm{I}, 1938$ to July I, I939, 4 I4 people who were in difficulty with high rate loan companies were interviewed. These $4 \mathrm{I} 4$ people were involved with 84 different loan companies for periods ranging from a few days up to $2 \mathrm{I}$ years each. They were involved in a total of 2,784 loans, with an average of a trifle under 7 loans per individual interviewed. These figures exclude those cases where the parties were involved wholly with the financing of conditional sales.

The annual interest rate charged varied from a low of $33 \%$ to a high of $1,353 \%$ on the loan itself. These interest rates where predicated upon straight loans and they do not in any sense of the word consider accumulated interest on pyramids of renewals. It was found that in many instances, after a few renewals, the face of the note consisted solely of pyramided illegal charges ... The borrowers had long since repaid the money lent, plus legal interest, so that all payments from that time were sheer tribute payments under duress.

In some instances it was impossible to compute the interest rate accurately, as sufficient information was not obtainable. For the most part such cases were those where the borrower had made a series of renewals. In those cases the borrower usually had no receipts or evidence of payment and an imperfect recollection of the facts. It was difficult to apply a formula which would fairly and accurately reflect the true interest rate. Beyond a doubr those cases would increase greatly the average interest rate reached. In many cases the interest rates on the renewals would have run well over $2,000 \%$. Nevertheless, the average interest rate per loan, without considering pyramids or renewals, was $218.42 \%$ annually; in other words, slightly in excess of. $18 \%$ per month.

In the actions instituted against four loan firms in Minneapolis in the fall of $193^{8}$, the Hennepin County Attorney generally alleged a cause of action for injunctive relief against the maintenance of a public nuisance and sought appointment and retention of receivership pending suit. Two of the cases later were carried to the Minnesota Supreme Court on appeal by defendants. While the opinions of that court were not rendered until after the passage of the Minnesota Small Loan Law', the decision in the Metro Loan Company case ${ }^{11}$ contains a recital of statistics on the operations of the defendant and develops some interesting and important law on the right of the state to enjoin usurious lending as a public nuisance. The public exposition of loan shark tactics in these cases, the expressed determination of the county attorney to ask for receivership of every company doing a loan shark business, and the announced intention of the attorney general on behalf of the state to come in and join with the county attorney in all cases against illegal lenders charged with being public nuisances were most importance developments in exposing the usurious loan situation in Minneapolis before the people in Minnesota.

The complaint in the case against Metro Loan Company is typical of the basis of the actions instituted by the State against usurious lenders in the fall of 1938 . The complaint charged that defendant "maintains a common or public nuisance in Hennepin County, Minnesota, and is engaged in habitually, continuously and repeatedly, openly, publicly, persistently and intentionally doing the acts hereinafter

to July I, I939 (Betrer Business Bureau of Minneapolis, Inc., 1939). This investigation was conducted by Charles W. Root, who, as assistant counsel for the Legal Aid Society of Minneapolis, also conducted most of the investigation for the Legal Aid Society in 1937.

${ }^{11}$ State ex rel. Goff v. O'Neil d.b.a. Metro Loan Co., 205 Minn. 366, 286 N.W. 3 16 (1939). 
set forth, all to the injury of the public and contrary to the public policy of the State of Minnesota." The complaint alleged that the defendant was engaged in the "loan shark business," the principal object of which was "to collect and extort illegal and usurious rates of interest, sometimes as high as five hundred thirty per cent $(530 \%)$ per annum, from wage earners who are forced by necessitous circumstances, such as sickness, birth of children, accidents, etc., to borrow small sums of money." Quoting now from Associate Justice Andrew Holt's majority opinion in the case: ${ }^{12}$

It is averred that the amounts of the loans made by defendant are small, varying from five to fifty dollars, that they are originally made for short terms, usually from one to six months, to be repaid in small monthly or semimonthly payments; that defendant advertises the business extensively, offering commissions to those bringing him customers; that he purposely selects the poor and necessitous wage earner, and exacts notes for the loans in amounts grossly in excess of the sums loaned; that defendant has made many hundreds of these usurious loans, many of which are outstanding at this time; that the legal remedies and defenses of these borrowers are inadequate and ineffective in that the borrowers are unwilling and financially unable to prosecute or defend their rights in court. These allegations are extensively amplified by showing the methods used to extort payment of the usurious loans, and the inability of the borrowers to get out of defendant's clutches once they are in.

... From examination of the books and evidences of indebtedness of defendant's business, taken over when appointed, the receiver makes an affidavit showing the existence of 595 loans, upon which there still appears unpaid in excess of $\$ 14,000$, although of the total sums loaned of $\$ 14,400$, over $\$ 20,000$ has been repaid. It is further shown that of these loans only four were of $\$ 100$ each; all the rest were in sums of $\$ 50$ and less. The interest rate of each loan is shown. Only in five cases was it less than roo per cent per annum. Those five were $76,82,87,94$, and 96 per cent per annum. In the other 590 loans the interest rate per annum would average well over 300 per cent, one exceeding I, 000 per cent.

In addition to the extreme variance of rates charged in individual cases and the unconscionable average interest rate per loan disclosed by the special investigations and court cases, the public exposures also crystallized the oppressive methods characteristic of loan shark practices. As shown by reports of social agencies the tactics used by the typical loan shark operator in acquiring, maintaining, and collecting loans created a serious social and economic evil. Twelve of the most typical and common evils that were connected with illegal small loan operations in Minnesota are summarized below. How the small loan law and regulations in Minnesota were developed and enforced to correct these evils will be shown later. Summarizing the loan shark practices exposed by investigations:

I. About roo high rate loan offices were operating in Minneapolis and St. Paul making loans generally of $\$ 50$ and less, charging average annual interest rates of about 220 per cent. Many debtors owed 7 or more lenders.

12205 Minn. at $37 x-372,374-375,286$ N.W. at $319,320-321$. 
2. Advertising extensively and openly soliciting loans clothed the loan shark with an outward appearance of respectability and legitimacy.

3. Cash bonuses were paid present customers who referred new borrowers.

4. Borrowers were cajoled or coerced into renewing loans constantly, being able to pay exorbitant interest only, or, in many cases, adding the accrued interest to the renewal amount.

5. Borrowers, unable to meet extortionate charges, borrowed from Peter to pay Paul, until they found themselves hopelessly owing many high rate loan companies.

6. Tricky transactions of the lenders in drawing loan contracts through several methods were used to confuse and conceal the true nature of the debt. One note, two notes, sometimes three notes were drawn or required to be signed in blank.

7. Receipts for payments were vague and indefinite, if given at all, and most borrowers had no idea of the status of their loans.

8. On final payments, notes were usually not returned; borrowers were furnished only the torn portion bearing their signatures.

9. Loans were limited to small amounts because lenders were unwilling to risk the borrower's defense of usury. This forced many borrowers to owe many different companies, with no practical means of relief through court actions.

Io. Court records revealed numerous suits against borrowers. Frequently garnishments were attempted and successful although not properly served.

II. Deceptive notices simulating process, pleadings or other legal notices were sometimes used to coerce and intimidate debtors.

12. Repeated telephone calls at work and home, constant harassing by collectors at all hours, contacting employers frequently, and many other harsh collection practices were employed.

All the facts and figures revealed in the investigations and court cases which exposed the usurious lending problem were well publicized in 1937 and $193^{8}$ and were well presented before the 1939 Legislature in support of a sound small loan bill. The Minnesota Small Loan Act was passed February 15, 1939, and went into effect June I, I939.

\section{Borrowers Protected Under the Minnesota Small Loan Law}

The Commissioner of Banks is the administrator of the Minnesota Small Loan Law. The Commissioner investigates the financial responsibility, experience, character, and general fitness of applicants for a license to conduct business under the law and approves or denies applications depending upon his findings as to the applicant's qualifications and whether the business to be conducted will promote the convenience and advantage of the community. He is required to examine the 
affairs, business, office, and records of each licensee at least annually and is empowered to make general rules and regulations and specific rulings, demands, and findings for the enforcement of the law.

The administration of the law by the Commissioner of Banks has been constructive and effective. From the outset, his policies and procedures have been designed to carry out the full meaning and intent of the law. His rules and regulations have been promulgated to protect the borrower to the fullest extent and yet are fair and unprejudiced to licensees operating under the law.

Immediately upon passage of the small loan law on February 15, I939, a number of companies applied for licenses to conduct business on its effective date. These early applications, however, were returned to the applicants pending the adoption of orderly procedural rules. On May 26, a few days before the Act took effect, the Commission announced the promulgation of preliminary rules and regulations and issued instructions for filing of applications on or after June $\mathrm{I}^{13}$ Under the pre. liminary rules and regulations, advertising of any nature was prohibited until a release date which was announced later after the early rush of applications was processed. Also, all advertising matter was reviewed and approved by the Commissioner's office before publication and distribution. In order to assure an orderly administration of the law during the organization and development stage, the Commissioner at first accepted only applications for licenses in Minneapolis, St. Paul, and Duluth. The number of licenses issued to any one company was restricted to prevent the possibility of a monopoly, and licensees were limited to making loans to borrowers residing within restricted, defined areas. These limitations were effective in assuring that the loan shark evil in Minnesota would be corrected first where it was known to exist.

Twenty-eight applications for licenses in Minneapolis, St. Paul, and Duluth were filed in the first hour of business on June $\mathrm{I}$, $1939 . .^{14}$ On June 7 , the Commissioner announced the issuance of the first 6 licenses, all for offices in Minneapolis and St. Paul. By that time, there were 35 applications on file for Minneapolis, 25 for St. Paul, and II for Duluth. ${ }^{15}$ After investigation, many of the applications for licenses were denied by the Commissioner, but none of the applicants appealed the decision. By the end of 1939, there were 85 licensed small loan offices, with the great majority located in the three large cities of Minneapolis, St. Paul, and Duluth.

On December 12, 1941, the temporary rules and regulations governing advertising were repealed and superseded by the "Rules of Fair Trade Practices and Advertising Standards for Licensees Operating Under the Minnesota Small Loan Act," which had been adopted by the Minnesota Association of Small Loan Companies on November I2, I94I. This code formulated by the trade association of the loan industry in Minnesota was adopted by the Commissioner as an experiment in selfcensorship and self-regulation. The success of the experiment is proven by the

${ }^{13}$ Commissioner of Banks, State of Minnesota, Bulletin of May 26, 1939. Re: Small Loan Application.

"Minneapolis Times, June I, 1939.

15 Id. June 7, 1939. 
continued, unamended existence of this code which regulates advertising standards of small loan licensees in Minnesota.

Effective February I5, I942, permanent rules and regulations governing the conduct of small loan licensees were promulgated to replace the temporary rules as amended. These rules and regulations were the result of lengthy study and collaboration with a committee of the Minnesota Association of Small Loan Companies. $^{16}$ In I945, a law was passed permitting administrative agencies of the state to issue rules and regulations. ${ }^{17}$ This statute prescribes reasonable notice, a fair hearing, findings of fact based on substantial evidence, and a precaution that such rules and regulations shall not exceed the powers vested by statute. It provides for review of rules and regulations by the attorney general and, upon approval by him, permanent filing with the secretary of state. The rules and regulations for small loan companies adopted under the procedure required by the 1945 law became effective October 2, I945, in substance reconfirming the 1942 regulations.

There has been no material revision of the small loan law in Minnesota since its passage. The rules and regulations for small loan companies have been only slightly altered except for revocation of the unusual provisions which were adopted primarily for an orderly beginning of administration by the Commissioner of Banks. At the outset, the Commissioner adopted rather stringent policies tending to limit the scope of operations of licensees. Although these policies have been moderated to some extent as confidence in the ethics and standards of the industry has been recognized, the methods and mode of operation remain subject to the protective provisions of the policy originally established.

Interpretations of the small loan law by the courts in Minnesota are rare and there has been no case challenging the validity of any section of the small loan statutes. The Commissioner of Banks on several occasions has requested opinions from the attorney general for clarification of specific sections of the law. These opinions ${ }^{18}$ relate either to the question of nonlicensees being subject to investigation by the Commissioner, or the right of a licensee to permit any other business to be conducted in the licensed office. The absence of any material conflict over the meaning of the statute and regulations can be considered as a tribute to the fair administration of the law by the Commissioner of Banks and the willingness of the licensees to cooperate and comply with his directives and policies.

Twelve typical evils connected with high rate lending operations prior to the passage of the small loan law in 1939, summarized from investigations, court cases, and other public exposures, were previously listed in this paper. The protective provisions of the Minnesota Small Loan Law and regulations and practices which have been adopted and relate to the correction of those conditions are set out for the purpose of comparison:

\footnotetext{
${ }^{16}$ Commissioner of Banks, State of Minnesota, Bulletin to Licensees, Feb. II, 1942.

${ }^{17}$ Minn. Stat. ANn. \$15.04I to 15.049, Laws of 1945, c. 452.

${ }^{19}$ Ops. Minn. AtT'y Gen. 29-A-8, Feb. I6, 1939; 29-A-8, Mar. 12, 1942; 53-A-8, Dec. 22, 1942.
} 
I. The maximum charge permitted by law is 3 per cent month on unpaid principal balances. No other charges whatsoever are allowed.

2. False, misleading and deceptive advertising is prohibited by law. All advertising must be in strict accord with the "Rules of Fair Trade Practices and Advertising Standards for Licensees under the Minnesota Small Loan Act."

3. A regulation provides that licensees may not offer or advertise gifts, allowances, gratuities or other monetary inducement of any character to borrowers, merchants, business groups or other persons to induce borrowing.

4. A regulation prohibits licensees from including accrued charges on an existing loan in the amount of a renewal.

5. To prevent the possibility of any borrower becoming involved in debt by owing many small loan companies, the licensees themselves, through an exchange bureau to which all companies within a lending area belong, have voluntarily adopted a ruling which prevents any person from having more than two small loan creditors. All applicants for loans from small loan licensees are cleared through the local exchange bureau and the two-loanlimit is effective throughout the state.

6. As required by law, the borrower receives a statement of his loan giving full particulars. A regulation provides that all blank spaces on documents must be filled in before the borrower signs.

7. As required by law, the borrower gets a receipt for every payment made, showing the amount applied to charges and to principal and the remaining unpaid principal balance.

8. Under the law, any borrower may make payment in advance in any amount at any time; on full payment, notes and security papers are stamped "Paid" and returned to borrower.

9. Up to the maximum limit of $\$ 300$, loans may be made for any amount needed by a borrower within his ability to repay.

ro. Regulations require licensees to maintain complete records on all suits and garnishments for inspection by the Commissioner of Banks.

Ir. The loans and business, including books, accounts, records and files of a licensee, are open for inspection and examination at any time by the Commissioner of Banks.

12. Borrowers may present particulars to the office of the Commissioner of Banks at any time they consider any licensed lender's method of operation objectionable or subject to criticism. Upon presentation of a complaint, the Banking Department thoroughly investigates the facts and when warranted requires a full accounting of the transaction from the licensee involved. Proper adjustment in any individual case or in the operating policy of the 
licensee is required whenever justified and the Commissioner will take such action as is deemed advisable to enforce the provisions of the law and regulations.

Consumer Loans in Minnesota After Fourteen Years Under the Small Loan Law

The credit structure in Minnesota now offers sources for installment loans to all classes of consumers with varying needs and credit standings. Statutes now provide for installment loans from banks at 6 per cent discount per annum with a maximum loan of $\$ 1,500,{ }^{19}$ from industrial loan and thrift companies at 8 per cent discount per annum plus fixed investigation fees with a maximum loan based on common capital, as well as from small loan companies at 3 per cent per month on unpaid principal balances with a maximum loan of $\$ 300$. Credit unions are also available to many consumers eligible for membership for loans at $\mathrm{I}$ per cent per month on unpaid principal balances.

The extent to which the small loan agencies have met the need for credit facilities and the type and nature of loans made by them are shown by the 1952 Consolidated Report issued by the Commissioner of Banks. ${ }^{20}$ The 108 licensed small loan offices in Minnesota made 195,722 loans totaling $\$ 39,6 \mathrm{r}_{4}, 883.14$ during the year and had Ir9,295 accounts totaling $\$ 21,307,674.69$ outstanding at the year end. The average size of loan made during $195^{2}$ was $\$ 202.40$, and 45,530 loans were made in amounts of $\$ 100$ or less. Over half of the loans (10r,654) were made on an unsecured basis. The small loan industry had $\$ 21,597,000$ invested in the business of making loans of small amounts to approximately 120,000 consumers in Minnesota.

The present geographical distribution of licenses reflects the type and size of communities which are serviced by small loan companies. Of the total ro8 licensed offices at the end of 1952,36 were located in Minneapolis and its suburbs, 27 in St. Paul and suburbs, II in Duluth, 3 in Rochester, 3 in St. Cloud, 2 in Winona, 2 in Austin, a total of 15 licenses in eleven other cities outside the Twin City area with populations in the 10,000 to 20,000 class, and the remaining 9 licenses in 9 cities ranging in population from 5,000 to I0,000. Thus, 68 per cent of the licenses are located in the Minneapolis-St. Paul area or in Duluth. These three cities are the only large urban areas of Minnesota where the industrial, trade and office workers who need small loan facilities are concentrated. Many of the smaller cities in Minnesota have experienced considerable growth in population over the past decade through the addition of industrial plants and distributing services. In these cases, the increase in wage earner and salaried population has been recognized by the Commissioner who has granted small loan licenses for the convenience and advantage of these commuities.

After fourteen years of experience under the law, significant are the opinions of

${ }^{10}$ Mins. Stat. Ann. $\$ \$ 48.153$ to 48.157 , Laws of 1945, c. 544 , as amended by Laws of $1947, c .314$.

${ }^{20}$ Report of the Comafissioner of Banks, State of Minnesota, for the twel.ve month period from Ja. I, 1952 throcgh Dec. 31, 1952, of SMall LoAN Companies Licensed Under Minnesota Statctes c 56 (1953). 
its administrator and the social welfare agencies who knew best the conditions as they existed prior to its passage and who have the closest contact with the segment of our population most likely to need and use small loan service.

The following quotations were published in $195^{2 . .^{21}}$

In a statement dated May I4, I952, Mr. A. W. Hoese, then Commissioner of Banks, comments on the Minnesota Small Loan Law and its results as follows:

Public records in Minnesota give clear evidence of the social evils that existed in the small loan field prior to the passage of the Minnesota Small Loan Act in I939 and it was the intent of the Legislature by this Act to stamp out the loan sharks. Immediately upon the effective date of the Act, the lending of small sums at exorbitantly high rates of interest ceased. Practically no cases have come to our attention of any direct lending activity at unlawful rates.

The absence of customer complaints and the growth of the small loan business in Minnesota over the past decade are clear proof of public acceptance of the law. The business is clearly an essential part of the consumer lending structure in Minnesota.

The Legal Aid Society of Minneapolis conducted an investigation of usurious loan operations in 1937. Reviewing conditions after passage of the law, Mr. Robert C. Holtze, Chief Counsel, in a letter dated May 15, 1952, made this statement:

We are pleased to report that no cases of usurious lending in the small loan field have come to the attention of this office in the past several years. Prior to the passage of the Uniform Small Loan Act in 1939 this office was constantly involved in defending victims of "loan shark" lending at rates far in excess of the legal limits.

The Better Business Bureau of Minneapolis also made a study of high rate loan companies prior to passage of the Small Loan Law. Mr. C. W. Shirk, Manager of the Bureau, stated as follows in a letter dated June 4, $x 952$ :

Since the enactment of the Uniform Small Loan Law in Minnesota a negligible number of complaints have come to us on small loan matters, most of these few cases arising from a misunderstanding of the law. Our experience leads us to conclude that compliance with the law and its administration by the state banking department are satisfactory.

Family Service of St.'Paul actively supported the passage of the Minnesota Small Loan Law in 1939 as a solution to the "loan shark" problem. On May I4, 1952, Mr. A. A. Heckman, Executive Secretary, wrote in part as follows:

Thirteen years have passed since our Legislature enacted the "Small Loan Law" and wiped out the "loan sharks" that had plagued the wage earners of this state for so many years. We have observed carefully the results of this legislation and are pleased to report that the benefits of this legislation exceed our expectations of over a decade ago.

${ }^{21}$ Small Loan Service in Minnesota (Minnesota Association of Small Loan Companies, June, 1952). 